\title{
Citizen news podcasts and engaging journalism The formation of a counter-public sphere in South Korea
}

\begin{abstract}
This study examines what roles citizen news podcasts of South Korea play, based on two unique concepts - carnivalism and engaging journalism. To this end, the current study content analysed the content of 11 citizen news podcasts that are most popular in this country and conducted interviews with 10 professional journalists. The findings reveal that through the use of comedic techniques such as humour, parody, and satire, the discourse of citizen podcasts transgresses existing social and cultural hierarchies and subverts a range of authoritative discourses by mainstream media. The analysis also finds that the discourse in citizen news podcasts takes on the nature of engaging journalism, which motivates ordinary individuals who are left largely disillusioned from mainstream journalism to engage in elitechallenging political action. Professional journalists admitted that citizen news podcasts provide an opportunity to re-evaluate the journalism norms and practices of South Korea.
\end{abstract}

Keywords: carnivalism, citizen podcasts, counter-public sphere, engaging journalism, public sphere, South Korea

\section{CHANG SUP PARK \\ Bloomsburg University of Pennsylvania, USA}

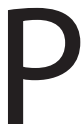

ODCASTING has largely leveled off today in South Korea (hereafter Korea). Since the introduction of podcasting in early 2011 in Korea, more than 4,000 podcasts are created and consumed each week (So, 2014). One notable trend is that podcasting is widely used for journalism by ordinary citizens who want to deliver and discuss topics of their own choice (Park, 2015). In other words, citizen-created podcasts focusing on current affairs, politics, or news attract a significant portion of news users of this country (Park, 2016). Almost every week, citizen news podcasts rank among the 'top 10 popular podcasts' (Podbbang, 2016).

Citizen news podcasts are increasingly becoming an alternative medium in Korea. Many citizen podcasts play a role in directing public attention to socio- 
political issues that were neglected by mainstream media (Lee et al., 2012; Yoo, 2011). Lampooning former President Lee Myung-bak (2008-2012) and raising criticisms again ruling elites, Naneun Ggomsuda (Naggomsu, meaning 'I am a Petty-Minded Creep') was a cult among young people while the show was running in 2011 and 2012. This podcast received the 2011 Democratic Media Award from the Korean Federation of Press Unions. For those reasons, many media scholars and political pundits argue that citizen news podcasts are gaining importance as an alternative journalism channel (Cho\& Hong 2013; Kim, 2011; Koo, Chung, \& Kim, 2015), functioning as a counterforce against the juggernaut of mainstream media (Cheon \& Chang, 2011; Na, 2011).

Against this backdrop, the current study examines the nature of an emerging form of journalism shaped by citizen news podcasts in Korea. The present research particularly pays attention to how citizen news podcasts serve both those who are enthusiastic about information seeking and those who have felt being excluded from the public sphere mainly driven by mainstream media. To this end, the present research draws on the concept of carnvalism, which is defined as a new participatory culture in which ordinary individuals use humor, satire, and parody to express their thoughts and resist the dominant power (Bakhtin, 1984a). This paper then suggests engaging journalism as a crucial nature of the citizen news podcasts of Korea.

\section{Literature review}

\section{Media landscape and the public sphere of South Korea}

More than four decades after the Korean War in the 1950s, Korean mass media have been under heavy control by authoritarian regimes, sometimes functioning as a government mouthpiece. In 1987, the general public of Korea protested massively against the ruling bloc, asking for democracy (Kim, 2000). Responding to the protests, the government loosened the control of mass media, but not completely. The government still maintained direct and indirect influence over two major broadcasters, KBS and MBC. This situation remains the same today. Unlike broadcasters, major newspapers gradually increased their autonomy. Particularly, three major newspapers (Chosun, Joongang, and Donga Daily) transformed themselves into self-declared political institutions. For instance, they directly and indirectly intervened in major election campaigns (Kang, 2005).

The mainstream media of Korea expanded their market share through close connection with the political power (Kang, 2005; Kim, 2010). The top three newspapers occupy about 60 percent of the newspaper market of Korea. The two major TV networks are extremely influential in the broadcast market. With a lack of fair competition and explicit support from the political power, those big 
media in Korea have prospered even with manipulative and biased news reporting (Kim, 2010; Park, 2015). For this reason, the mainstream media of Korea have long been criticized for being slanted toward conservatism, unfair reporting, and manipulation of public opinion (Chang, 2008; Kim, 2005; Lee, 2011).

Since the late 1990s, the internet has created a breathing room for different and anti-government voices. Many internet and smartphone users started making alternative media as a tool of free expression of opinions with the goal of creating a new public sphere outside mainstream media (Lee, 2012; Park, 2013). The internet has allowed anonymously scattered citizens to mobilise each other against the big media. Through online cafés and social networking sites, Korean citizens have disseminated information, initiated public discussions, and organized collective action (Hsu et al., 2013). But the cyberspace had to suffer from the censorship by the government's legal and administrative actions (Park, 2015).

In this situation, critical citizens sought for another new media channel that can represent their voice (Park, 2013). Podcasts appeared at this moment. Citizens noticed two major merits from podcasting. First, podcasting was relatively free from regulations. Podcasts as a new medium were not subject to the same KCC (Korea Communications Commission) regulation as traditional broadcasters. Podcasting is still unregulated by KCC although the government is preparing a regulation bill. Some citizen podcasters used foreign servers to circumvent any possible intervention or censorship by the Korean government (Baek, 2012). Second, the cost of content creation and delivery is very low in podcasting (Menduni, 2007). With a simple recording set and a small room, anyone can make a podcast and upload it to iTunes or YouTube. As a result, ordinary individuals have enthusiastically introduced their podcast shows and used them as a new conduit of information and expression (Park, 2015).

Citizen podcasts have hooked many Koreans, young and old, as they provide critical information and opinions on the dark realities of modern-day Korea. A lot of citizen podcasts specialise in satire and parody of political elites and practice investigative journalism to uncover the government's missteps and politicians' wrongdoings (Jo, 2015). Thereby, citizen podcasts play the role that traditional mass media failed to do, delivering the messages that people should know to become informed citizens. Citizen podcasts also focus on broadcasting the views of ordinary citizens, instead of the established classes. As a result, citizen podcasts have gained explosive support from the general public. According to a survey in 2012, the reliability of Naggomsu was 40 percent, more than double the 17.2 percent of the three major newspapers (Lee, 2012). The popularity of citizen news podcasts reflects a widespread belief that the mainstream media in this country serve the ruling elites and their own interests at the expense of 'truth' (Kim, Lee \& Park, 2016).

The recent changes in Korean media landscape can be theoretically explained 
by the concepts of the public sphere and counter-public sphere. According to Habermas (1996), the public sphere refers to an area in social life where individuals can come together to freely discuss and identify social problems, and through that discussion influence political action. The notion of the public sphere assumes significance with regard to the role of mass media as an agenda setter and a watchdog of political power. But when mass media do not play the proper roles of journalism and audiences are excluded by largely elitist and inaccessible media systems, people get frustrated and do not trust mass media any longer. In such a situation, individual citizens start to create methods to express their voices and seek new media that reflect their opinions. The increased prevalence of internet-based and wireless technologies has enabled an unprecedented level of creation of media content by ordinary citizens. As Korean citizens have felt marginalised from the public sphere provided by mass media, the need of an alternative form of journalism has become stronger.

Through blogs, video-sharing and other forms of participatory publishing, citizens are able to set social agendas themselves, subverting the traditional model of the press as the primary arbiters of the public agenda. New media allow for the circumvention of traditional mass media control (Bowman \& Willis, 2003; Hartley, 2005; Livingstone, 1999). Citizen journalism can, therefore, be viewed as a direct response to lapses in the performance of the traditional mass media role in the public sphere.

Citizen journalism forms a counter public sphere that seeks to challenge the dominant public sphere of a society beyond mere independence from it (Downey $\&$ Fenton, 2003; Kluge \&Negt, 2016). The notion of the counter-public sphere helps us better understand the increasingly important role of citizen journalism today. A counter-public sphere resists dominant communications, offering citizens forms of solidarity that are grounded in a collective experience of marginalisation and expropriation (Downey \& Fenton, 2003). Citizen podcasts in Korea permit ordinary individuals to construct an inexpensive virtual counter-public sphere against the mass-media public sphere, as Castells (2007, p. 249) aptly said, 'The emergence of mass self communication offers an extraordinary medium for social movements and rebellious individuals to build their autonomy and confront the institutions of society in their own terms and around their own projects.' Therefore, this study argues that the counter-public sphere created by citizen news podcasts help us figure out the underlying power struggle between ordinary citizens and ruling elites including the mainstream media of Korea.

\section{Carnivalism}

Although the concept of counter-public sphere may be useful in modeling the phenomenon in which citizen podcasts are being used as an important journalism conduit in Korea, it is not certain exactly what aspects of citizen podcasts 
have contributed to the formation of a counter-public sphere. Citizen news podcasts in Korea are not easy to define with traditional journalism principles because they usually do not abide by the norms of journalism. Many citizen podcasts are full of humor, satire, and parody. They are even not hesitant to spit out foul words or slangs, which are hardly acceptable in mainstream journalism. Many citizen podcasts abound with non-stop chats about public issues and criticisms toward the establishment including politicians (Lee, 2012). In order to identify the accurate features of citizen news podcasts that are believed to contribute to the formation of a counter-public sphere, the current study employs the notion of carnivalism.

A carnival is a Western culture. Its original meaning is an entertaining public square, which anyone can join and enjoy regardless of social status or economic class (Crossley et al., 2004). In a carnival, people seek fun and joy by participating in various activities and by communicating with others. A carnival is also a special event where resistance is allowed. Carnivals have historically been a space for participants to use various means to have fun themselves while making fun of the existing authorities and hierarchies.

In other words, a carnival not only provides a space for festivity and laughter, but also creates an arena where people can resist dominant power with free expression of non-legitimate voices against governing elites. At a carnival, people attempt to oppose the official hierarchy that presents the world as unified, ideal, and fixed (Bakhtin, 1984a). Through a carnival, official hierarchies of order are ridiculed and the social and political authority is temporarily inverted. Bakhtin (1963, pp. 122-123) said, 'What was suspended in carnival first of all was hierarchical structure and all the forms of terror, reverence, piety, and etiquette connected with it.' But it should be noted that Western carnivals mainly aim to serve to renew society and the world (Bakhtin, 1984b), as a release for impulses that threaten the social order or norms (Cohen, 1993), as a social transformation (Turner, 1982), or as a tool for different groups to focus attention on conflicts and incongruities by embodying them in 'senseless' acts (Abrahams, 1972).

Although Koreans used to enjoy carnivals at the community level until the last dynasty era (Chosun Dynasty), such a tradition has been suppressed by military and authoritarian regimes on the pretext of economic development. Until the mid-1990s, carnivals were very occasionally allowed and usually prepared by ruling authorities. Like in the West, Koreans were given occasional opportunities of venting their frustrations and anger toward the governing people at carnivals offered by authoritarian governments.

Going through 1980s and 1990s, Koreans regained self-confidence as they frequently participated in democratic processes, including massive demonstrations against the ruling bloc. Further, the wide spread of the internet since the late 1990s gave Koreans news tools to make their voices heard to governing 
elites as well as other fellow citizens (Hauben, 2007). The highly-wired infrastructure has allowed Koreans to capitalise on digital tools to organise voluntary collective actions during election campaigns and protests (Sams \& Park, 2013). Combining the characteristics of the growing autonomy of citizens and the wide availability of the internet resulted in embracing a new collective culture on the part of people (Park, 1998).

Against such a backdrop, ordinary individuals of Korea have gradually learned how to organise and enjoy carnivalistic participation without depending on the arrangement by the government. One good example is the 2002 World Cup held in Korea. During the games, millions of Koreans took to a main public square downtown in Seoul and entertained themselves by joining massive cheering like a festival. Unlike any government-initiated public events or carnivals, the massive cheering was organised mainly by individual citizens, who used their cell phones to mobilise people (Chang, 2005). Throughout the 2000s, carnivalistic collective action organised by ordinary individuals has become a new cultural trend in Korea. Whenever an important public affair occurred, people organised candlelight protests that were inundated with creative picket signs of diverse causes and witty performances on a free speech podium, such as skits, dancing, and singing (Ok, 2011). In 2008, when hundreds of thousands of people lit candles to protest the resumption of US beef imports, the public square in downtown Seoul was again transformed into a place of an enormous political carnival.

In many ways, Korean carnivals today are not the same as Western carnivals. First, carnivalism in recent Korea is not a temporary but a lasting culture, while Western carnivals are one-time events. Many Koreans do not think a carnival is a just momentary event for fun or entertainment (Kyoto Journal, 2016). Instead, through carnivalistic engagement, Koreans believe they can consistently exhibit the power of citizens. Second, Korean carnivals are leaning more toward resistance rather than enjoyment. They are often initiated to express complaints and ask for political or social reforms. In other words, Koreans are using carnivalistic events to demonstrate citizen power to the ruling bloc. Lastly, Korean carnivals are attracting many young people into political processes. Young people tend to combine participation in social and political affairs with play, parody, humour, wit, and caricature to express their feelings and opinions rather than direct criticism. 'Fun'-oriented carnivalistic participation resonates with the comparatively unrestrained participatory culture of young people on the internet (Lee \& Jung, 2008). Overall, Koreans' experience in collective action and carnivalistic participation has contributed to 'the formation of a new public sphere' (Park, 1998, p. 442).

Drawing on the above reasoning, the current study speculates that the spread of carnivalistic participatory culture in today's Korea has exercised a significant 
impact on the rise of citizen news podcasts. Accordingly, in the next section, the paper analyses how citizen podcasts incorporate carnivalism into their programming. Before undertaking an analysis, this study additionally reviews what rhetorical devices constitute carnivalistic discourse. A number of studies suggest that humor, satire, and parody are essential in a carnival (Bakhtin, 1963; Foot \& Schneider, 2002; Mascha, 2008).

Humor is 'a mechanism that relieves the subject of the accumulated elements of aggressivity hidden within the unconscious' (Mascha, 2008, p. 74). Humour is a relief mechanism from a deep anxiety or repression and the need to escape from such a condition. From the past, political humour used to be 'a familiar vehicle for expressing popular disdain and opposition against repressive regimes' (Badarneh, 2011, p. 306). Political humor as a reaction to the great concentration of power is a safe release from a superior force (Schutz, 1977). Political humour enables people to vent social and economic frustrations, thereby allowing them to release suppressed desires and freedoms (Badarneh, 2011).

Satire is a discourse that people use to make fun of someone and relieve people from certain oppression (Mascha, 2008). Satire momentarily creates laughter and a sense of relief accompanied by the freedom from the oppressing subject. Satire creates 'a space of freedom through this counter-hegemonic project raising the political consciousness of the disempowered people and taking part to an expression of resistance' (Mascha, 2008, p. 82). A meaningful satirical discourse is one that mocks the existing rule and degrades the dominant hegemony. A satirical discourse succeeds when it draws the hidden identity of oppression and reveals it at the center of public attention. Satire initiates laughter, fosters resistance, and makes people feel free from the ideological oppression of the dominant discourse.

Lastly, carnivalistic resistance is often expressed via parody. Parody is defined as 'an imitation of the style of a particular writer, artist, or genre with deliberate exaggeration for comic effect' (Oxford Dictionaries, 2016). That is, parody is an imitation that is set against an original or falls far short of the real thing. According to Bakhtin (1984b), parody is a kind of double-voicing, as when a speaker acts out what another has said in a comic manner. Double-voicing deflates the seriousness of a statement, thus inserting 'a new semantic intention into a discourse which has, and which retains, an intention of its own' (Bakhtin, 1984b, p. 189). Political parody is often used for raising a counter meaning to the ruler's words and to ridicule the political agenda of the ruler (Badarneh, 2011). A parody creator relies on the ruler's discourse but 'introduces into that discourse a semantic intention that is directly opposed to the original one' (Bakhtin, 1984b, p. 193). As a result, the voice of the parody creator clashes with the voice of the ruler who controls the dominant discourse. 


\section{Method}

In order to examine how citizen news podcasts of Korea can be understood by the concepts of carnivalism, this study mainly conducts as a case study focusing on Naggomsu, a representative citizen podcast in Korea. This study carried out a qualitative content analysis by scrutinizing the content of Naggomsu. Additionally, this research content analyzed ten most popular citizen news podcasts, which were chosen by the number of downloads in a podcast portal, Podbbang. The current research also conducted interviews with ten professional journalists of Korea in order to examine the impact of citizen podcasts on mainstream journalism. Interviewees were selected from ten different media outlets, three from newspapers, three from TV networks, three from online newspapers, one from a cable TV channel. The interviews were conducted in December, 2016. The average age of the interviewees is 36 and they have on average 11 years of journalism experience.

\section{Findings}

\section{Carnivalism in Naneun Ggomsuda}

Naggomsu started as an informal chat show by four men ridiculing Lee Myungbak, the then president of Korea, as well as offering sharp criticisms of contemporary political affairs. Its first episode was released on 28 April 2011, and the last one on the eve of the presidential election day (19 December 2012). There were a total of 71 episodes. During its two-year life, Naggomsu saw an average of two million downloads for each episode and became one of the world's most downloaded political podcasts in Apple's iTunes store (Baek, 2012). Naggomsu

\section{Table 1: Top 10 popular citizen news podcasts of South Korea}

\begin{tabular}{|l|c|c|}
\hline \multicolumn{1}{|c|}{ Titles } & $\begin{array}{c}\text { Weekly } \\
\text { Downloads }\end{array}$ & $\begin{array}{c}\text { Regular } \\
\text { subscribers }\end{array}$ \\
\hline Kim Yongmin's Briefing & 141,198 & 121,077 \\
\hline Politics changes by informed citizens & 38,502 & 47,782 \\
\hline Chung Bongju's Junkookoo & 169,105 & 186,114 \\
\hline YiYiJay by Dr. Lee and Writer Lee & 223,062 & 234,779 \\
\hline Seo Youngseok's The Criticism & 5,723 & 5,899 \\
\hline Clean Area & 24,144 & 33,331 \\
\hline I don't want to know it & 36,030 & 66,422 \\
\hline Gobal News & 63,434 & 47,237 \\
\hline Chatting on Current Affairs & 22,692 & 13,657 \\
\hline Public Opinion is the most important & 19,635 & 4,345 \\
\hline
\end{tabular}

Note: According to the statistics during the week of January 1 to 7, 2017, by Podbbang, the biggest podcast portal in South Korea. 
played an important role in directing public attention to social and political issues that were overlooked by mainstream media, and its popularity triggered the mushrooming of similar types of citizen podcasts across the country.

In terms of journalistic production, Naggomsu was the brainchild of four men who had backgrounds and characteristics that distanced themselves from traditional and elite journalism. This show was a kind of role-playing performance. The leading host was Kim Ou-joon, the founder of Ddanzi Ilbo, a political parody website. Chung Bong-ju, a former lawmaker, played the role as a very talkative panelist. He habitually cut off the others midsentence and punctuated almost every comment with laughter. Choo Chin-woo, a reporter of an alternative newsweekly SisaIN, played the role as a presenter of newsworthy topics. He often debunked political scandals mainstream media rarely paid attention to. Kim Yong-min, a former radio commentator, was the producer of the show.

Naggomsu was not a news-heavy outlet. This study content analyzed 10 randomly chosen episodes of the show according to the following four categories: real news, satire, parody, and commentary. Real news stories were the most dominant category, making up 40 percent of all the content. Satire (28 percent), commentary (21 percent), parody (11 percent) followed news.

The four panelists employed casual and lively conversation techniques when delivering content. As expected, the show was rife with humor. The four panelists constantly chuckled. The show favored everyday language of ordinary people. Complex jargons, difficult words, and elite words were hardly used. For example, the following expressions were frequently heard: 'Pack your luggage' (quit this job), 'His neck was cut' (he was fired), 'He was bounced off' (He lost political power), 'Shut up' (Be quiet), and 'He ate up all' (He filled all the important governmental positions with his aides).

In addition to everyday language, provocative words were frequently used in this show. Even expletives were heard: 'The situation is doggy mess, ' fxxxing,' 'son of bitch.' These curses and swears were usually directed toward former President Lee, corrupt politicians, 'political' prosecutors, and mainstream media journalists.

Jung: What are the public officials doing in this doggy nation? They do not listen to anybody. They just care about themselves.

Kim Ou-joon: Uhm, they just strive to survive for themselves, never caring about others, fxxxxxx.

Jung: That's why we cannot even think of collaboration between officials and government agencies.

Kim Ou-joon: Only President himself...

Jung: He damn decides all.

Kim Ou-joon: He used to do things all himself. (from episode 2, 12 May 2011)

While humourous comments never stopped in the show, Naggomsu essentially concentrated on creating a tone of resistance, which is not a typical case in the 
mainstream journalism of Korea. At the introduction and ending of each episode, the four panelists shouted the catchphrase of the show: 'Let's not be intimidated! Let's say whatever we want, even if we're thrown into jail tomorrow.'

One prime example of resistance from the show is its intense focus on the scandals involving former President Lee and corrupt power elites. During the 2011 Seoul mayoral election, Naggomsu exercised its agenda-setting power with a number of scoops. For example, in episode 12, Choo reported that Na Kyungwon, the ruling party's candidate frequently visited a luxury skin-care clinic where the annual membership fee is $\$ 90,000$. Choo's report played a decisive role in drawing the attention of the electorate because the wealth gap between the rich and the poor was an important campaign issue at that time. Na sued the programme for libel, but the prosecution found no evidence of Choo's guilt. Choo was also the first to report that President Lee had bought a very expensive lot to build his retirement residence, not in his name but in his son's name. Soon, this report developed into a big political scandal. Many political analysts said that Naggomsu overwhelmed the mainstream media during the election cycle (Lee, 2012; Lee, 2011).

Another important method of resistance in the show was its constant attempts to re-interpret major issues. The show constantly raised questions to the explanations or analyses proposed by politicians or mainstream media. It challenged dominant frames about an issue, by overturning, twisting, and re-investigating the issue. The re-interpretation of a major issue involved three steps. First, the four panelists collected all available clues, contexts, and backgrounds regarding the issue. Second, they suggested several hypotheses based on their own collected information. They often said, 'We raise several scenarios about...' The last step was to conjecture the truth of the issue: 'There is enough circumstantial evidence to show...' Drawing on such a unique method, Naggomsu revealed contradictions and conspiracy of an issue and attested to the intrigue of the establishment.

The content analysis finds that satirical criticism is another important aspect of political carnivalism in Naggomsu. In June, 2011, the main opposition party and civic groups requested that the free lunch benefit should be given to all elementary and secondary school students in Seoul. At this, then-Seoul-Mayor Oh Se-hoon announced that he would hold a referendum for that issue, objecting to the opposition party's suggestion (Choe, 2011). Naggomsu satirised Oh's attitude, pointing out that he was simply an avatar of former President Lee because the president constantly objected to the expansion of social welfare.

Jung: Mayor Oh is in the same party as His Highness who also served as Seoul mayor in the past. Therefore, we should say that $\mathrm{Oh}$ is a person as lofty as His Highness.

Kim Ou-joon: He is a complete successor of His Highness. 
Jung: His Highness is pouring $\$ 18$ billion in restoring the four major rivers of Korea, which have not caused any problem so far. In a very similar way, Oh is also considering spending astronomical money to expand the Han River in Seoul.

Kim Ou-joon: His Highness is a perfect role model of Oh.

Parody was often employed as a crucial rhetorical tool when Naggomsu reported news addressing the alleged nefariousness of former President Lee. For instance, in every parody song, President Lee was described as a petty-minded creep just like the title of the show. In many parodies, President Lee was portrayed as a person who always lied, hid something, and attributed blames to others, not to himself. The following is one of the most frequently used parodies in the show: 'As President, I will do my best to ignore and distress citizens.'

As reviewed earlier, carnivalistic participation is an emerging culture in recent Korea. Going through a series of participatory experiences, Koreans have learned how to voluntarily join or organise carnivalistic activities to express their dissent to the established order and to address their own agendas to ruling elites (Kim \& Kim, 2009). This article argues that the new culture of carnivalistic participation has carried over into the citizen news podcasts of Korea, gratifying news consumers' desires for resistance toward the establishment. Naggomsu's effective utilization of carnivalism in its program implies that the show knew that the carnivalistic content would appeal to ordinary individuals. As a result, Naggomsu has helped position the podcast platform as a new journalism genre (Jo, 2015)

The impact of Naggomsu's carnivalism on mainstream journalism is significant. More than anything, Naggomsu stimulated journalists to attend to and re-evaluate the rules and assumptions that dictate journalistic practice. In the interviews with this study, mainstream journalists said they realised that crafting news in an easy, entertaining, and analytic way should be considered important beyond the traditional narrative format of journalism. A television reporter with 10 years of journalism experience said, 'Listening to Naggomsu, many journalists have noticed how their stories are condescending and one-way with little consideration of what news audiences want to read, listen, or view.' Another reporter from a cable TV said that journalists now should rethink about their news writing styles and news audiences.

Eight out of the 10 professional journalists interviewed also agreed that Naggomsu made them cover more news items that are critical toward the governing people. An online newspaper reporter said: 'In terms of manpower, Naggomsu cannot be compared with any traditional media outlet. But Naggomsu focused on several important items, such as former President Lee and his aides. The show did not fear anything and just dug into leading politicians' scandals without hesitation, which mainstream media neglected.' 
Park and Kim (2012), regarding the journalistic implications of Naggomsu, argued that the show has suggested a new journalism model of post-objectivity, post-rationality, and post-elitism to Korean journalism.

\section{Engaging Journalism}

In addition to Naggomsu, this study conducted a content analysis of 10 citizen news podcasts. The results reveal that 9 out of 10 citizen podcasts take a critical tone toward leading politicians, mainstream media, or the government. Five citizen podcasts supported liberal candidates in elections. Therefore, in terms of objectivity and fairness, citizen podcasts might be embroiled in controversy. But their watchdog role stands out. From the perspective of podcast listeners, citizen news podcasts seem to be doing a satisfactory journalism job because a wide range of audiences are consistently consuming citizen podcasts (Park, 2016). In order to explain this phenomenon, this study suggests the concept of engaging journalism.

In the face of the transforming media environment, journalism is compelled to provide 'added value' to its audiences in addition to its original mission (Heikkilä \& Ahva, 2015). In his recent speech at the Reuters Institute for the Study of Journalism, Picard (2009) poignantly suggested an important task today's journalism should undertake. He said, 'Journalism must innovate and create new means of gathering, processing, and distributing information so it provides content and services that readers, listeners, and viewers cannot receive elsewhere.' Picard added that journalists must provide sufficient value to engage digital audiences. Drawing on Picardo's insight, this study conceptualises engaging journalism as a type of journalism that focuses on providing added values to audiences to attract them to public affairs and democratic processes.

This study finds that one of the added values in citizen news podcasts is the offering of a counter-public sphere to citizens. As pointed out previously, for more than six decades, the mass media public sphere of Korea has been a closed realm for the establishment, excluding ordinary citizens' voices and demands. In such a situation, individual citizens have long wished to have a channel that can represent them. Citizen podcasts answered such a wish, presenting better-appealing stories about the world than many of the legitimate news outlets do (Lee, 2012).

All of the 10 citizen podcasts analysed were found to have the characteristic of investigative journalism, focusing on revealing what lies behind public issues. Explanation and analysis of important public issues is a big part of many news stories in citizen podcasts. As a result, citizen podcasts hold government officials accountable to the legal and moral standards of public service and keep leaders conscious about society's expectations of integrity and fairness (Cheon \& Chang, 2011). This study also finds that three citizen podcasts analysed explicitly aim to fix the power imbalances between governing people and the governed. The above findings suggest that citizen podcasts are concerned more with motivating people 
to engage in the democratic process by providing unique explanations about the context and background regarding an issue or event than simply transmitting known facts. It is an important responsibility of journalism to take the initiative to report on major public problems in a way that advances public knowledge of possible solutions and helps people participate in the public life (Lambeth, 1998; Rosen, 1999). Beyond such a role of journalism, Korean citizen podcasts encourage ordinary individuals to build alternative discourse (Lee, 2012), by providing a counter-public sphere.

This study finds that carnivalism is another added value of citizen news podcasts. All the 10 citizen podcasts analysed focus on delivering serious news, but in entertaining ways. They use the formats of talk show, rant sessions or comedy skits. In an interview, Chung of Naggomsu said, 'I'm a clown. I speak and act on people's behalf' (New York Times, 2011). As a result, the distinction between news and entertainment often becomes blurry and inextricably intertwined in citizen podcasts. It appears that citizen podcasts resist the binary distinction between news and entertainment, making the categorisation largely ineffectual.

The combination of news and entertainment in citizen podcasts functions as an effective strategy to draw readers' attention. According to a survey, people's main motivations for listening to Naggomsu are information seeking, entertaining seeking, relaxation, and escape (Cho \& Hong, 2013). The survey results indicate that people appreciate that citizen podcasts provide programmes that are politically funny and drip with satire and parody (Lee, 2012).

The carnivalism of citizen podcasts particularly appeals to young people. Across the world, journalism scholars and pundits deplore the trend that young people are turning off from the news (Blumler, 2011; Starr, 2012; Young, 2009). They blame youth's disinterest in conventional news, bemoan their ignorance, and charge them with apathy and laziness (Putnam, 2000). However, such a claim lacks evidence. Katz (1997) aptly pointed out, 'for the young, culture is politics, personal expression and entertainment all fused together' (p. 130). Wilson (2011) argues that young adults appreciate the sarcasm, irony, parody, and satire pervasive in social networking sites. Digital generations do not want to feel marginalised by mainstream news, which usually present information in a serious and conventional way. Additionally, young adults, who cannot find outlets to vent their anger from depressing economic and political situations, are drawn to the unrestrained lampoons in podcasts to relieve their frustration and disappointment (Kim, 2012; Lee et al., 2012). Therefore, it is very likely that news content coated with humour, satire, and parody would draw more young generations to citizen podcasts.

Overall, based on the analysis, the current study posits that citizen news podcasts demonstrate a new type of journalism, named 'engaging journalism'. 


\section{Conclusion}

Today, Korea is passing through a revolutionary change in media development. Since the early 2011, numerous citizen podcasts focusing on public affairs, politics, and news have expanded their realm, sometimes jeopardising the mainstream media that have dominated the public sphere of Korea over the last five decades. This research sought to investigate how the podcast has become a promising journalism tool, based on three unique concepts - carnivalism, engaging journalism, and counter-public sphere.

More than anything, this study finds that Korean citizen podcasts are characterised by carnivalism. Through the use of comedic techniques such as humour, parody, and satire, the discourse of citizen podcasts transgresses existing social and cultural hierarchies. Satiric and ludicrous in nature, citizen podcasts playfully subverts a range of authoritative discourses and provide a vehicle for both comic criticism and emotional catharsis. Citizen podcasts not only serve to lampoon the establishment, but also provide an alternative news venue to news consumers.

The carnivalistic podcasts of Korea also should receive attention in terms of engaging journalism. Citizen podcasts aim to engage listeners toward important public issues and democratic participation. Podcasts have become an alternative medium, providing carnivalistic content and by enabling individual users to take advantage of such carnivalistic content for the purpose of elite-challenging participation. Through such a process, citizen podcasts contribute to forming a counter-public sphere against the mass media pubic sphere.

Korean mainstream journalists have long neglected the fundamental principles of journalism. Instead mainstream journalists showed more interest in controlling information dissemination in and through the structured journalism space. Korean journalists have taken for granted the status of a structured institution that operates with twisted professional practice, such as collusion with the political power and manipulative attempts of public opinion (Kang, 2005; Park, 2015). The carnivalism of citizen news podcasts inevitably challenges the professional logic of journalism, although professional journalists still exercise greater influence in the journalism space. Citizen podcasts pose uncomfortable challenges to journalists' jurisdictional claims to the news process. Podcasting has fostered the formation of a counter public sphere in Korea. Carnivalistic citizen podcasts are the space for the public to express dissent to the established order, creating an 'anti-structural' sphere, where dominant social relations are inverted or leveled.

The present study argues that the recent uptake of citizen news podcasts offers journalists opportunities to reflect on current journalism assumptions, identities, and practices. Citizen news podcasts stimulate journalists to think about what it means to be a journalist. In other words, citizen podcasts provide journalists a reflective lens by which they can look back on the rules and conventions of their 
professional practice. Citizen podcasts are an important case of new journalistic practice emerging in the age of 'post journalism' (Park \& Kim, 2012). While a departure from typical journalism routines might be painful, from citizen podcasts mainstream journalists may gain useful ideas that appeal to audiences. This is, of course, just the beginning of the conversation regarding the future of journalism.

This study has some suggestions for future research. First, citizen news podcasts are created by non professional journalists and most of them do not seek profits. Future studies must examine whether citizen news podcasts could become a legitimate form of journalism beyond the current status as experimental journalism. Second, this study shows that the carnivalistic nature of citizen news podcasts in Korea is closely related to the unique media system and political culture of Korea. To see whether this study's findings could be generalised to other nations, future research needs to conduct comparative studies.

\section{References}

Abrahams, R. (1972). Christmas and carnival on Saint Vincent. Western Folklore, 13(4), 275-289.

Badarneh, M. (2011). Carnivalesque politics: A Bakhtinian case study of contemporary Arab political humor. Humor, 24(3), 305-327.

Baek, C. (2012). Podcast Heyday. Kyunghyang Weekly. Retrieved from http://weekly. khan.co.kr/khnm.html? mode $=$ view\&code $=115 \&$ artid $=201202141848451$

Bakhtin, M. (1963). Problems of Dostoevsky's poetics [Edited and translated by Caryl Emerson]. Minneapolis, MN: University of Minnesota Press.

Bakhtin, M. (1984a). Rabelais and his world. Bloomington, IN: Indiana University Press.

Bakhtin, M. (1984b). Problems of Dostoevsky's poetics. Minneapolis, MN: University of Minnesota Press.

Banta, J. (2012 April 6). David versus Goliath: Podcasts rise as alternative media in South Korea. Retrieved from http://tribune.cnumedia.com/news/articleView. html?idxno=10058

Blumler, J. G. (2011). Foreword: The two-legged crisis of journalism. In Franklin, B. (Ed.), The future of journalism (pp. 439-441). London, UK: Routledge.

Bowman, S., \& Willis, C. (2003). We media. How audiences are shaping the future of news and information. Reston, VA: The Media Center at the American Press Institute.

Chang, W-Y. (2005). Online civic participation, and political empowerment: Online media and public opinion formation in Korea. Media, Culture \& Society, 27(6), 925-935.

Chang, W. Y. (2008). The cyber balkanization and structural transformation of the public sphere in Korea. Journal of Contemporary Eastern Asia, 7(2), 29-48.

Cho, S., \& Hong, S. (2013). How does a social issue moderate diffusion of innovation: A case of podcasting with Naneun Ggomsuda in Korea. International Journal of Advancements in Computing Technology, 5(12), 350-355.

Choe, S. (2011, November 1). By lampooning leaders, talk show channels young people's anger. The New York Times. Retrieved from http://www.nytimes.com/2011/11/02/ world/asia/lampooning-leaders-talk-show-channels-young-peoples-anger-in-southkorea.html?_r=1\&ref=-southkorea

Choi, S., \& Lim, C. (2013). Analysis of the relationships between national TV news, 
Twitter of the Seoul mayoral candidates, and 'Naneun Ggomsuda' during the 2011 Seoul mayoral election. Broadcast \& Communication, 14(4), 5-35.

Cheon, K., \& Chang, I. (2011). Naneun Ggomsuda rocks politics. SisaIn, October 21, p. 215. Cohen, A. (1993). Masquerade politics. Berkeley, CA: University of California Press.

Crossley, N., \& Roberts, M. (2004). After Habermas: New perspectives on the public sphere. London: Blackwell.

Downey, J., \& Fenton, N. (2003). New media, counter publicity and the public sphere. New Media \& Society, 5(2), 185-202.

Foot, K., \& Schneider, S. (2002). Online action in campaign 2000: An exploratory analysis of the US political web sphere. Journal of Broadcasting \& Electronic Media, 46(2), 222-244.

Habermas, J. (1996). Between facts and norms: Contributions to a discourse theory of law and democracy. Cambridge, MA: MIT Press.

Hankyoreh. (2011). The meaning of Seoul mayoral election. Novermber 6. Retrieved from www.hani.co.kr/arti/opinion/editorial/504160.html.

Hartley, J., \& Notley, T. M. (2005). User-led content and self-creating communities: History repeating itself? Understanding 'internet radio' in the context of the development of radio. Radio in the World: Radio Conference 2005, RMIT University, Melbourne.

Hauben, R. (2007). Online grassroots journalism and participatory democracy in South Korea. In Korea Yearbook (2007) (pp. 61-82). Brill.

Haygood, D. M. (2007). A status report on podcast advertising. Journal of Advertising Research, 47(4), 518-523.

Heikkilä, H., \& Ahva, L. (2015). The relevance of journalism: Studying news audiences in a digital era. Journalism Practice, 9(1), 50-64.

Hollander, B. (1995). The new news and the 1992 presidential campaign: Perceived vs. actual political knowledge. Journalism \& Mass Communication Quarterly, 72(4), 786-798.

Hsu, C. L., Park, S. J., \& Park, H. W. (2013). Political discourse among key Twitter users: The case of Sejong city in South Korea. Journal of Contemporary Eastern Asia, 12(1), 65-79.

Jo, K. S. (2015). Rhetorical analysis of a political satire podcast, Naneun Ggomsuda. Master's thesis, San Diego State University.

Kang, M. (2005). The struggle for press freedom and emergence of 'unelected' media power in South Korea. In J. N. Erni, \& S. K. Chua (Eds.), Asian media studies: Politics of subjectivities (pp. 75-90). Malden, MA: Blackwell.

Katz, J. (1997). Clueless in the newsroom. Hotwired, October 23. Retrieved from http:// hotwired.lycos.com/synapse/katz/97/42/katz3a_text.html

Kim, J. (2012). Evolve into Homo smartcus. Seoul, South Korea: Haenam.

Kim, K. (2005). The effects of internet on the participation in collective action: Focusing on '2002 candle-light demonstration." Hankook Sahuehak, [Korean sociology], 40(1), 183-211.

Kim, S-H. (2000). The politics of democratization in Korea: The role of civil society. Pittsburgh, PA: University of Pittsburgh Press.

Kim, M., \& Kim, J. E. (2012). The influence of trust in mainstream media and political anxiety on intention to listen to a political satire: A case of South Korea. The 65th Annual Conference of World Association for Public Opinion Research, June 15.

Kim, Y. C., \& Kim, J. W. (2009). South Korean democracy in the digital age: the candlelight protests and the internet. Korea Observer, 40(1), 53-83.

Kim, S. (2010). Media market and publicness. Seoul, South Korea: Hanul.

Kluge, A., \& Negt, O. (2016). Public sphere and experience: Analysis of the bourgeois and proletarian public sphere. New York: Verso Books. 
Koo, C., Chung, N., \& Kim, D. J. (2015). How do social media transform politics? The role of a podcast, Naneun Ggomsuda in South Korea. Information Development, 31(5), 421-434.

Kyoto Journal. (2016). Korean protest culture. Retrieved from www.kyotojournal.org/ the-journal/society/korean-protest-culture/

Lambeth, E. B. (1998). Public journalism as a democratic practice. In E. B. Lambeth, P. E. Meyer, and E. Thorson (Eds.), Assessing public journalism (pp. 15-35). Columbia, MO: University of Missouri Press.

Lee, C., \& Jung, E. (2008). A study of the characteristics of youth participation through the candle culture festivals against the import of US beef. Communication Science Studies, 8(3), 457-491

Lee, J. (2011). The podcast dedicated to his highness, I wish his highness to listen to it. Media Today, July 22.

Lee, K., Lee, Y., Hwang, K., Chae, J., Cheon, H., \& Kwon, S. (2012). A critical analysis of $<\mathrm{I}$ am a weasel $>$ and its implications. Korea Association for Communication and Information Studies, 58, 74-105.

Lee, K-S. (2012, August). Mobile activism and its local scenes in Korea. INTER-ASIA ROUNDTABLE 2012: Methodological and Conceptual Issues in Cyber Activism Research, August 30-31, National University of Singapore.

Lee, M. (2012). The frame and discourse of the Report $<\mathrm{I}$ am KKomsu $>$. Masters thesis of Kyungpook National University, Kyungpook, South Korea.

Lee, Y. (2012). Re-examining Naneun Ggomsuda. Seoul, South Korea: Culture \& Science.

Mascha, E. (2008). Political satire and hegemony: A case of 'passive revolution' during Mussolini's ascendance to power 1919-1925. Humor, 21(1), 69-98.

Menduni, E. (2007). Four steps in innovative radio broadcasting: From quicktime to podcasting. Radio Journal: International Studies in Broadcast \& Audio Media, 5(1), 9-18.

Na, J. (2011). Podcast 'Naggomsu' challenges mainstream media. The Korea Times, November 11. Retrieved from www.koreatimes.co.kr/www/news/nation/2011/11/113 98580.html

Nason, P. (2005). Is podcasting the new radio? Washington Times, April 7. Retrieved from http://washtimes.com/upi-breaking/20050407-042946-2811r.htm

Ok, H. (2011). New media practices in Korea. International Journal of Communication, $5,320-348$.

Oxford Dictionaries. (2017). Parody. Retrieved from https://en.oxforddictionaries.com/ definition/parody.

Park, C. S. (2016). Citizen news podcasts and journalistic role conceptions in the United States and South Korea. Journalism Practice, 1-20.

Park, C. (2013). Political carnivalism and an emerging public space: examination of a new participatory culture on Twitter. International Journal of Electronic Governance, 6(4), 302-318.

Park, H. (1998). The informatisation and computer mediated communication in Korea: An application of Habermas 'Public sphere theory.' In Han, S. (Ed.), Habermas and the Korean debate (pp. 421-444). Seoul: Seoul National University Press.

Park, K. (2015). Audio revolution, podcasting. Hankyoreh Daily. Retrieved from www. hani.co.kr/arti/society/society_general/692533.html

Park, Y., \& Kim, K. (2012). An exploratory study for understanding post-journalism era-Focusing on the case of Naneun Ggomsuda. Journal of Korea Regional Communication Research, 9, 141-169. 
Picard, R. (2009). Why journalists deserve low pay. Presentation at Reuters Institute for the Study of Journalism, University of Oxford, May 6, 2009.

Podbbang. (2016). www.podbbang.com

Rosen, J. (1999). What are journalists for? New Haven, CT: Yale University Press.

Sams, S., \& Park, H. W. (2014). The presence of hyperlinks on social network sites: A case study of Cyworld in Korea. Journal of Computer-Mediated Communication, 19(2), 294-307.

Schutz, C. E. (1977). Political humor. Cranbury, NJ: Associated University Press.

So, S. (2014, September 26). The era of podcast broadcasting. ET News. Retrieved from http://www.etnews.com/20140923000368

Starr, P. (2012). An unexpected crisis: The news media in postindustrial democracies. The International Journal of Press/Politics, 17(2), 234-242.

Strother, J. (2011, December 14). VOA. Retrieved from www.voanews.com/a/hit-southkorean-podcast-sparks-controversy--135652353/149580.html.

Taylor, P. (1992). Political coverage in the 1990s: Teaching the old news new tricks. In J. Rosen \& P. Taylor (Eds.), The new news vs. the old news: The press and politics in the 1990s. New York: Twentieth Century Fund Press.

Turner, V. (1982). Celebration: Studies in festivity and ritual. Washington, DC: Smithsonian Institution Press.

Turner, V. (1982). From ritual to theater: The human seriousness of play. New York: PAJ Publications.

Wilson, J. (2011). Playing with politics: Political fans and Twitter faking in post-broadcast democracy. Convergence, 17(4), 445-461.

Yoo, C. S. (2011). Naneun Ggomsuda: A new phenomenon in the social network age. PoliNews. Retrieved from http://www.polinews.co.kr/news/articleView. html?idxno=87023

Young, S. (2009). The decline of traditional news and current affairs audiences in Australia. Media International Australia, Incorporating Culture \& Policy, 131, 147-159. hani.co.kr/arti/society/society_general/692533.html.

\section{DrChang Sup Park is assistant professor of Mass Communications at Bloomsburg University of Pennsylvania, USA. cpark@bloomu.edu.}

